\title{
THE TRADING SPACE IN INPRES MARKET OF LHOKSEUMAWE CITY (STUDY OF BEHAVIOUR ASPECT)
}

\author{
Dela Andriani', Wahyu Utami ${ }^{2}$, Wahyuni Zahrah ${ }^{3}$ \\ Program Studi Magister Teknik Arsitektur Fakultas Teknik Universitas Sumatera Utara \\ Jl. Perpustakaan St. J07 Building, Medan, 20155, Indonesia \\ *Email: ${ }^{2}$ andriani.dela90@gmail.com, 2wahyuutami_dn@yahoo.com, 3wahyuni_zahrah@yahoo.com
}

\begin{abstract}
This research was begun from the phenomena of the use of unlimited space at Pasar Inpres in Lhokseumawe. The behavior of using space which intervene public space for personal interest is called territoriality behavior. The objective of this research was to find out the influence of human territoriality behavior on setting as the interaction between market users and their activity space. Territoriality is emphasized on personalization, labeling, domination, and control. This research used descriptive qualitative method with rationalistic approach. The data were gathered by conducting field observation, based on human behavior and supported by behavior mapping. The conclusion of the research is that territoriality behavior, based on personalization, tends to familiarity among territory owners. Territoriality based on labeling leads to one's behavior in labeling his territory into three forms. Besides that, based on domination, it leads to the behavior of using public facility, roads which is used for parking lot and for selling place which influence the circulation of market users. Meanwhile, territoriality behavior, based on control, can be seen in the used elements, either they are massive or not, and in the form of the owners in maintaining their territory.
\end{abstract}

Keywords: Setting, Personalization, Labeling, Domination, Control.

\section{PENDAHULUAN}

Ruang sebagai sebuah manifestasi terukur dari pola perilaku manusia, mengindikasikan kecenderungan perilaku/intervensi yang terjadi di dalamnya. Hal ini menunjukkan bahwa ada perilaku yang menunjukkan kepemilikan atas suatu ruang, yang disebut dengan teritori. Teritori artinya adalah wilayah sedangkan teritorialitas adalah sebuah wilayah yang dianggap telah menjadi haknya. Kepemilikan seseorang akan sesuatu atau suatu ruang akan terlihat dari kecenderungannya mempertahankan ruang tersebut, dengan cara memberi tanda, identitas atau semacamnya. Batas juga dapat dimasukkan ke dalam kategori ini. Kecenderungan ini disebut dengan teritorialitas. Julian Edney (1974, dalam Laurens, 2004) mendefinisikan teritorialitas sebagai sesuatu yang berkaitan dengan ruang fisik, tanda, kepemilikan, pertahanan, penggunaan yang eksklusif, personalisasi dan identitas. Termasuk di dalamnya dominasi, kontrol, konflik, keamanan, gugatan akan sesuatu, dan pertahanan.

Pasar Inpres Lhokseumawe merupakan salah satu dari pasar tradisional yang ada di Kota Lhokseumawe. Pasar ini beroperasi mulai pukul 06.00-13.00 WIB. Berbagai jenis barang dagangan diperjual belikan di pasar ini yang dimulai dari kebutuhan pangan hingga sandang. Aktivitas yang bervariasi ini tentunya mempengaruhi penataan pasar yang begitu kompleks. Namun, terdapat beberapa permasalahan, antara lain yaitu teritori yang tidak teratur. Ketidakteraturan sering sekali menimbulkan pemahaman yang salah mengenai batas-batas teritori setiap pengguna pasar. Berdasarkan latar belakang dan permasalahan yang ada tersebut, maka pertanyaan penelitian dirumuskan untuk menemukan konsep teritorialitas dalam penggunaan ruang pada 
Pasar Inpres Kota Lhokseumawe. Penelitian ini mengambil fokus mengenai teritorialitas berdasarkan personalisasi dan penandaan serta dominasi dan kontrol.

$\begin{array}{ccr}\begin{array}{c}\text { Perilaku } \\ \text { personalisasi }\end{array} \text { dan penandaan. Untuk } & \text { danitas berdasarkan }\end{array}$ memperjelas teritori, orang cenderung melakukan personalisasi terhadap teritorinya. Pada sebuah permukiman, beberapa cara personalisasi dapat dilakukan dengan cara memberikan peluang kepada tetangga untuk memahami satu dengan yang lain dan menciptakan suasana yang kompak (gotong royong, membantu memperbaiki rumah tetangga, dsb) (Brown dan Wesner, 1985, dalam Halim, 2005). Cara ini membuat orang bisa membedakan antara penduduk asli dan orang luar. Hal ini akan membuat pemilik rumah merasa aman karena pengawasan tidak dilakukan olehnya sendiri, tetapi juga oleh tetangganya. Personalisasi dapat menghasilkan rasa keterikatan pada sebuah tempat dan meningkatkan perasaan nyaman "seperti di rumah" (Becker \& Coniglio,1975, dalam Halim, 2005).

Haryadi dan B. Setiawan (1995 dalam Dwars Soukotta dkk, 2014) mengartikan bahwa teritori sebagai batas dimana organisme hidup menentukan tuntutannya, menandai serta mempertahankannya terutama dari intervensi pihak lain. Penandaan juga dapat diwujudkan dalam bentuk verbal dan non verbal. Bentuk verbal dapat diwujudkan dengan ucapan yang mewakili kepemilikan. Sedangkan Wujud non verbal menurut Rapoport (1982 dalam Judy O Waani, 2012) dapat dibagi menjadi 3, yaitu; 1) Fixed-feature elements (elemen bentuk tetap), pada dasarnya jarang berubah. Umumnya berhubungan dengan elemen arsitektur seperti dinding, langit-langit dan lantai. Termasuk juga penyusunan elemen-elemen tersebut, jalan-jalan dan bangunan pada kota; 2) Semifixed-feature elements (elemen bentuk semi tetap), penyusun seperti perabot rumah, tirai, tanaman atau elemen-elemen lansekap; 3) Nonfixed-feature elements (elemen bentuk tidak tetap): berhubungan dengan manusia sebagai penghuni, seperti perpindahan ruang (proksemik), posisi dan postur tubuh (kinesik), gerakan tangan dan lengan, ekspresi muka dan ekspresi tubuh lainnya. Penataan perabot atau penataan ruang akan meningkatkan kualitas teritori terhadap seseorang. Pemberian batas ruang seperti kaca , perabot yang membatasi antara ruang tamu dan ruang keluarga akan menjaga teritori si pemilik rumah dari intervensi tamu terhadap ruangruang lain yang terdapat di rumah tersebut. Teritorialitas juga bisa diwujudkan dengan gerakan tubuh, seperti gerakan tangan, ekspresi muka dan lain-lain. Orang lain akan mengetahui barang tersebut adalah milik kita apabila kita memperlihatkan bahasa tubuh dengan memegang barang atau memasang ekspresi wajah dan posisi badan menghadap barang tersebut.

Perilaku teritorialitas berdasarkan dominasi dan control. Kontrol menurut Altman (1975) dalam Burhanuddin (2010) diartikan sebagai mekanisme mengatur batas antara orang yang satu dengan orang yang lainnya dengan menggunakan tanda-tanda yang menyatakan bahwa tempat tersebut ada yang memiliki. Batas-batas ini diartikan sebagai sebuah pengontrolan, misalnya dengan menggunakan elemen tetap seperti dinding, kaca dan sebagainya. Kepemilikan atau hak dalam teritorialitas tergantung kepada persepsi yang bersangkutan (Fisher, 1984 dalam Laurens, 2004). Persepsi tersebut ada yang benar dan ada juga yang salah. Teritori ini mencakup legal atau tidaknya sebuah kawasan. Seseorang yang telah memiliki daerah teritori merasa bahwa dirinya berkuasa atas daerah tersebut dan berusaha mengendalikannya terlepas dari benar atau tidaknya daerah teritori tersebut miliknya atau bukan.

\section{METODE PENELITIAN}

Metode penelitian Ruang Berjualan pada Pasar Inpres Kota Lhokseumawe (Kajian Aspek Perilaku) menggunakan metode kualitatif deskriptif dengan pendekatan rasionalistik. Pengamatan di lapangan menggunakan pemaknaan empiri, selanjutnya dalam mengolah data dilakukan secara kualitatif (rasionalistik kualitatif), sebagai prosedur penelitian yang menghasilkan data deskriptif berupa kata-kata tertulis atau lisan yang disimpulkan dari hasil wawancara dan perilaku yang diamatai (Moleong, 1993, dalam Burhanudin). Teknik pengumpulan data dilakukan dengan observasi lapangan berdasarkan perilaku manusia yang didukung pemetaan perilaku. Metode Place Centered Maping digunakan berdasarkan pengamatan setting dan metode Person Centered Maping berdasarkan perilaku dan pergerakan manusia dalam setting. Pemetaan perilaku pada Pasar Inpres Kota Lhokseumawe akan dilakukan pada tiga durasi. Durasi ini 
ditentukan berdasarkan pola perjalanan (trip pattern) aktivitas dan pergerakan. Pola kegiatan dan pergerakan ini diawali dengan proses permulaan (pergerakan pembukaan lapak atau los, peletakan barang dagangan dan melayani pembeli, yaitu pada pukul 06.00-07.00 WIB. Pola kedua adalah pada saat kegiatan jual beli terbilang tinggi (pukul 08.00-10.00 WIB). Sedangkan pola terakhir dilakukan pada saat aktivitas para pedagang mulai berakhir (pukul 12.00-13.00 WIB). Pola terakhir ini dilakukan untuk melihat bagaimana para pedagang mengatur teritorinya sebelum mereka pulang.

\section{HASIL DAN PEMBAHASAN}

Lokasi penelitian terletak di Pasar Inpres Kota Lhokseumawe. Tepatnya di Kecamatan Bhanda Sakti (Gambar 1). Penelitian difokuskan pada satu koridor di pasar (Gambar 2) yang dianggap menjadi satu titik yang mempunyai aktivitas terpadat. Panjang koridor ini \pm 113 meter, dengan sampel pedagang sebanyak 64 sampel. Sampel ini terdiri dari pedagang kios 24 unit, los 19 unit dan pedagang kaki lima 21 unit.

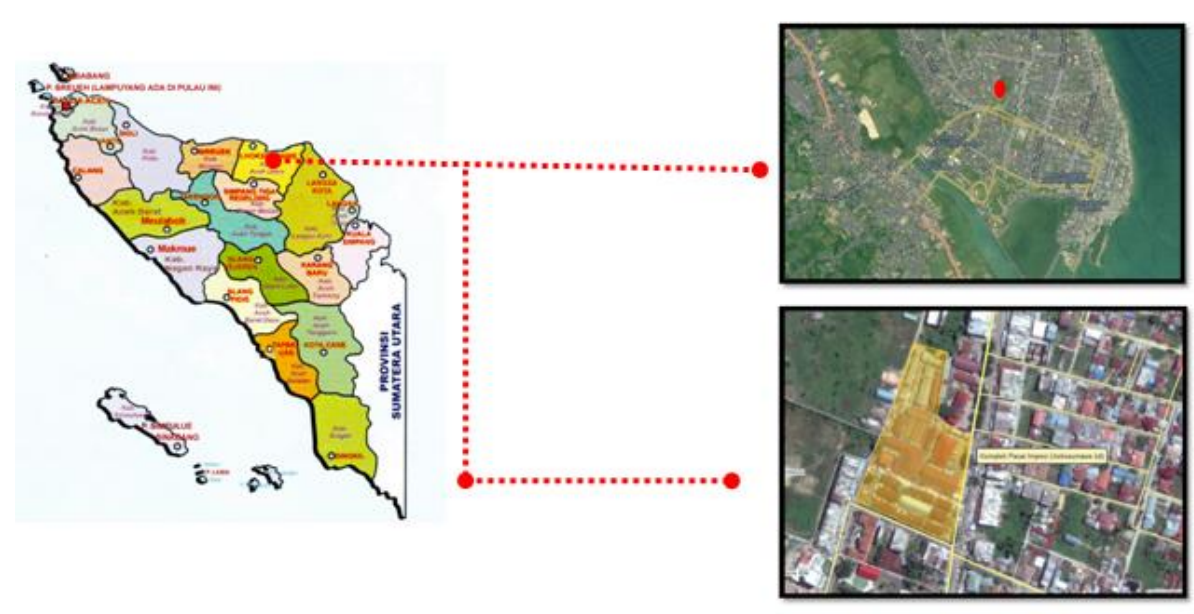

Gambar 1. Lokasi Penelitian
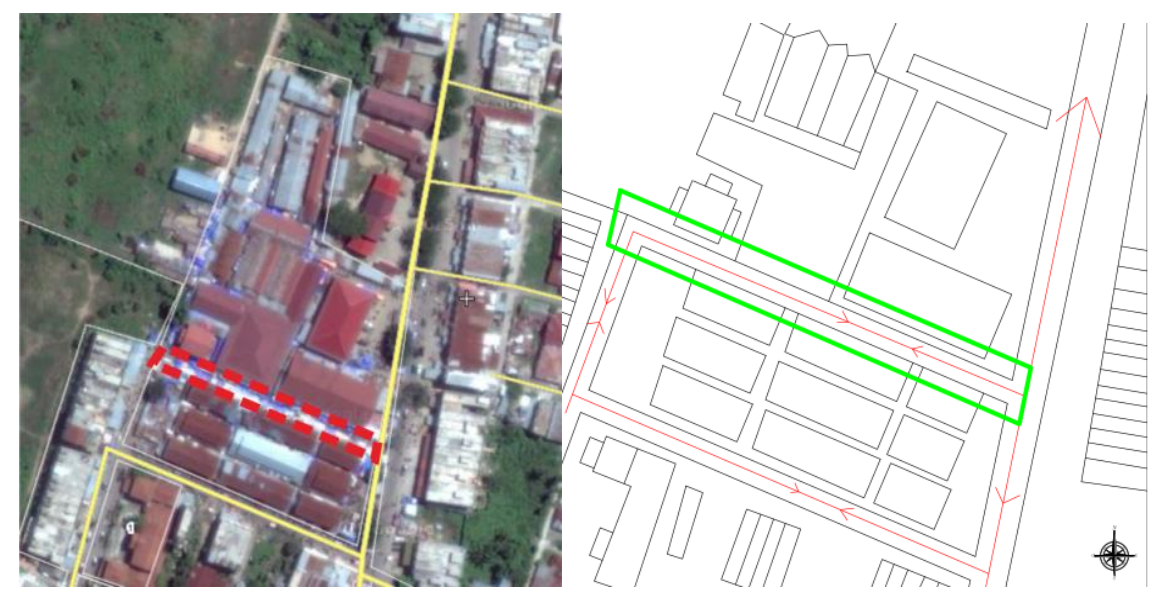

Gambar 2. Gambaran Lokasi Penelitian 
Perilaku teritorialitas berdasarkan personalisasi. Personalisasi dapat menghasilkan rasa keterikatan pada sebuah tempat dan meningkatkan perasaan nyaman "seperti di rumah" (Becker \& Coniglio,1975, dalam Halim, 2005). Berdasarkan hasil kuisioner, 100 persen pedagang saling mengenal. Bahkan mereka mengetahui nama dan alamat masing-masing. Namun, ada beberapa waktu yang dimanfaatkan pedagang untuk mempererat hubungan mereka, yaitu menegur, berkunjung, saling membantu dan saling mengobrol.

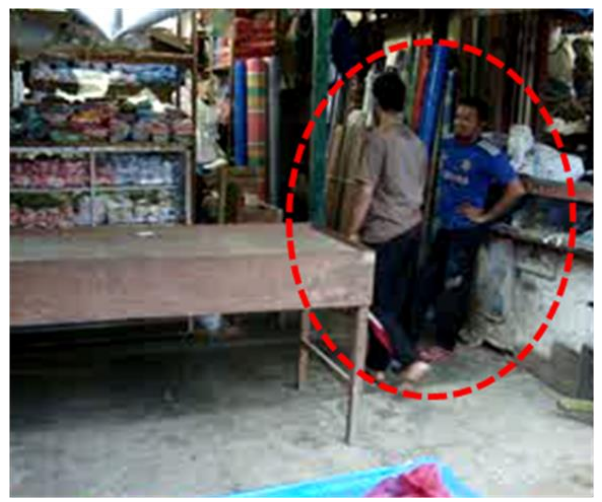

Gambar 3. Perilaku Obrolan

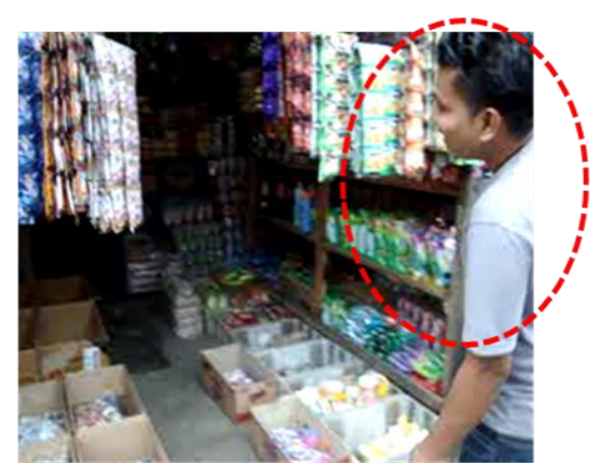

Gambar 4. Perilaku Menegur

Berdasarkan hasil kuisioner, mayoritas pedagang melakukan perilaku menegur dengan persentase 48 persen. Selanjutnya disusul dengan berkunjung sebesar 32 persen, saling membantu 14 persen, dan mengobrol 2 persen. Tetapi perilaku ini hanya dilakukan di waktuwaktu tertentu. Perilaku personalisasi yang paling banyak terjadi adalah pada pukul 12.00 13.00 WIB, karena pada jam tersebut pedagang sedang beristirahat. Hal ini dikarenakan aktivitas yang sangat padat. Personalisasi juga dapat dilihat pada perilaku penataan barang dagangan. Mereka juga mempunyai momen untuk berkumpul yaitu pada saat gotong royong (13\%), ketika ada musibah (16\%), ketika ada sebuah acara $(22 \%)$ dan lain-lain (22\%). Selain itu, tidak jarang juga kita temukan dagangan antara 2 pemilik teritori tidak berbatas (Gambar 5) dan hanya mereka sajalah yang tahu batasnya. Tetapi, hal ini sangat sedikit ditemukan. Perilaku ini menandakan bahwa sudah terjalin personalisasi yang kuat antara 2 pemilik teritori tersebut.

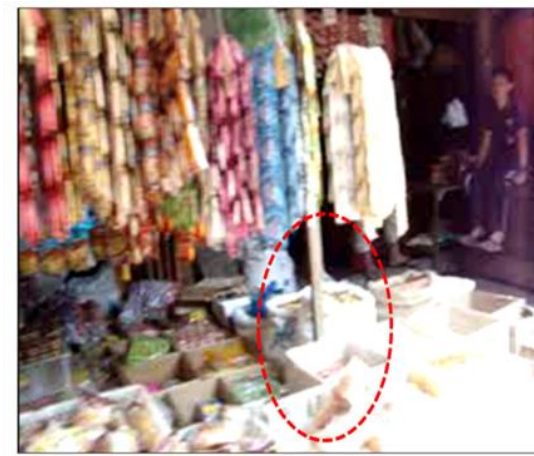

Gambar 5. Penataan Barang yang Tidak Diketahui Batasnya

Personalisasi juga terlihat pada hubungan antara pembeli dan pedagang. Pada area penelitian, 83 persen pembeli mengenal keseluruhan pedagang. Bahkan 67 persen diantaranya selalu berbelanja di pedagang yang sama. Personalisasi antara pedagang dan pembeli yang terjadi pada area penelitian terlihat pada perilaku peneguran dan obrolan. Intensitasnya juga bervariasi, dimulai dari mengobrol setiap kali datang (16\%), terkadang mengobrol (67\%) dan tidak pernah mengobrol $(17 \%)$. Selain itu, personalisasi juga terlihat hal-hal yang sensitif, seperti meminjam uang. 27 persen dari pembeli pernah meminjam uang/berhutang kepada penjual dengan alasan sering berbelanja di tempatnya. Meskipun persentasenya kecil, namun perilaku ini menandakan bahwa hubungan antara pembeli dan pedagang sangatlah erat. Berdasarkan kaitannya terhadap ruang, personalisasi menciptakan ruang bersama yang terdiri dari dua orang, tiga orang dan seterusnya, berada pada waktu-waktu tertentu dan pada tempattempat tertentu.

Segala perilaku ini dilakukan untuk menciptakan rasa aman dan kekerabatan antara pemilik teritori dan antara pedagang dan pembeli. Hal ini sejalan dengan teori yang menyatakan bahwa perilaku personalisasi dapat diwujudkan dengan cara memberikan peluang kepada tetangga untuk memahami satu dengan yang lain dan menciptakan suasana kompak seperti gotong royong, membantu tetangga, tersenyum, dll (Brown, 1985 dalam Halim, 2005). 


\section{Perilaku teritorialitas berdasarkan} penandaan. Bentuk kepemilikan teritori seseorang adalah menandainya. Hal ini merupakan sebuah kemestian yang sudah lumrah dilakukan. Berdasarkan kuisioner, 70 persen responden memilih menandai teritorinya. Wujud non verbal menurut Rapoport (1982 dalam Judy O Waani, 2012) dapat dibagi menjadi 3, yaitu elemen bentuk tetap, elemen semi tetap dan elemen bentuk tidak tetap. Pada area penelitian, Elemen bentuk tetap terlihat pada seluruh kios yang terdiri dari pemakaian material masif (dinding, lantai dan langit-langit).

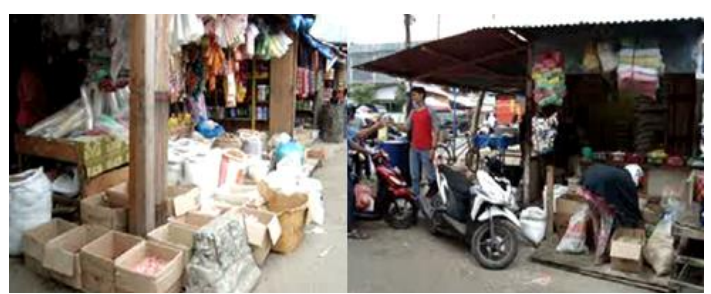

Gambar 6. Elemen Bentuk Tetap

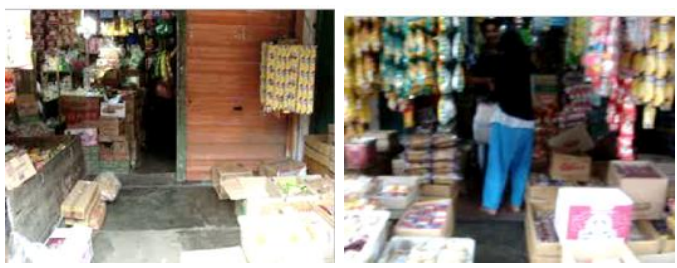

Gambar 7. Elemen Bentuk Tetap

Elemen semi tetap merupakan elemen favorit yang digunakan pada area. Ia merupakan elemen yang terbanyak digunakan. Elemen ini sendiri terdiri dari papan (alas atau meja), tenda maupun perabot (Gambar 8, Gambar 9, Gambar 10). Dari ketiga bahan ini, yang paling banyak digunakan adalah papan yang diwujudkan dalam bentuk meja (52 persen). Sedangkan elemen bentuk tidak tetap terlihat pada permainan postur tubuh, posisi tubuh dan gerakan lengan dan tangan (Gambar 11, Gambar 12).

Berbicara tentang pengaruh penandaan terhadap ruang, maka dapat diuraikan berdasarkan ketiga elemen di atas. Pertama, elemen bentuk tetap, menciptakan ruang yang sudah pasti dan sukar dirubah. Waktu tidak berpengaruh terhadap elemen ini.
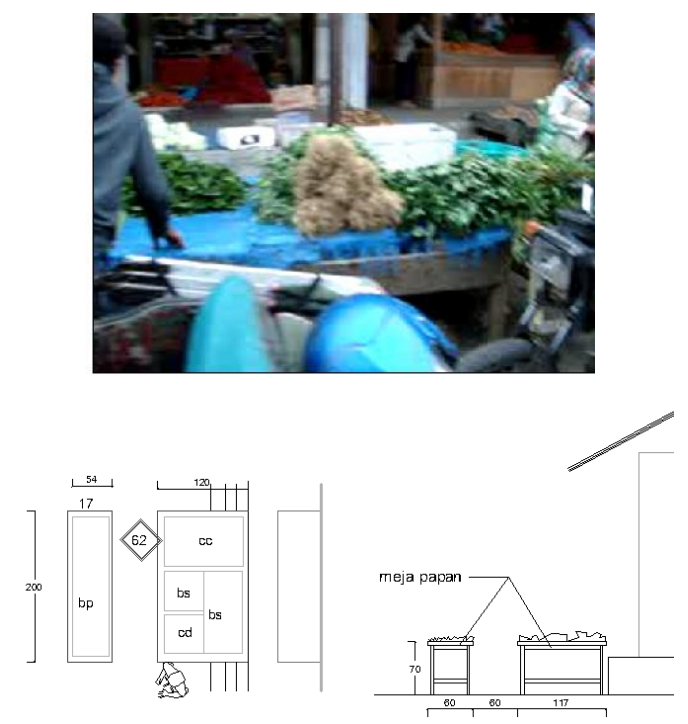

Gambar 8. Elemen Bentuk Semi Tetap dengan Papan

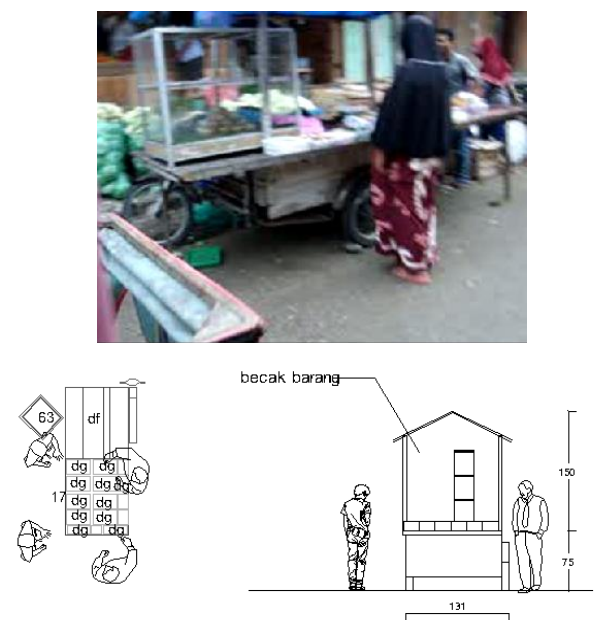

Gambar 9. Elemen Bentuk Semi Tetap dengan Perabot
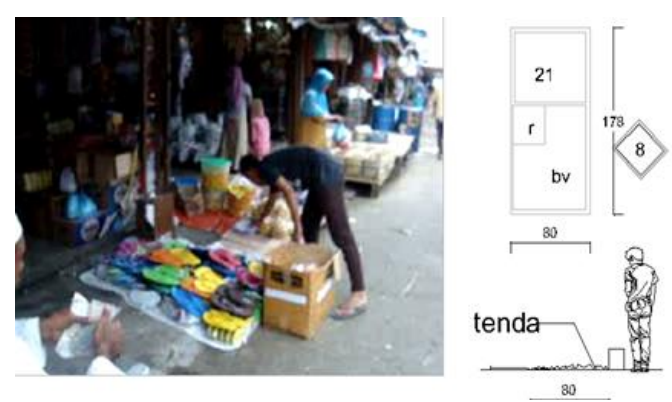

Gambar 10. Elemen Bentuk Semi Tetap dengan Tenda

Kedua, elemen bentuk semi tetap, menghasilkan ruang yang dapat dipindah kapan saja dan di mana saja. Elemen ini paling banyak terdapat pada pukul 06.30-07.00 WIB. Ketiga, elemen bentuk tidak tetap, menghasilkan ruang 
yang tidak terbatas yang mengitari teritorinya. Elemen ini paling banyak menempati ruang pada pukul 06.30-07.00 WIB.
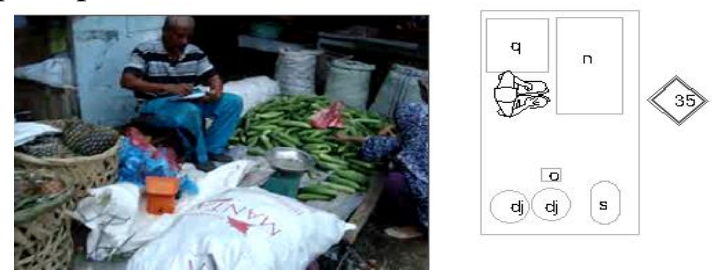

Gambar 11. Elemen Bentuk Tidak Tetap dengan Gerakan Lengan dan Tangan
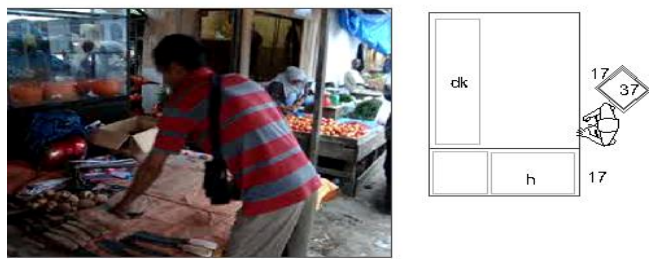

Gambar 12. Elemen Bentuk Tidak Tetap dengan Gerakan Lengan dan Tangan, posisi tubuh serta postur tubuh

Berdasarkan waktu, ada beberapa waktu yang membuat pasar ini lebih ramai, yaitu pada idul fitri dan idul adha. Sedangkan pada akhir pekan, pasar ini keadaannya sama dengan harihari kerja lainnya. Perlu diketahui bahwa, pemerintah hanya menyediakan wadah berjualan. Sedangkan yang mengatur peletakan lapak/los/kios adalah pedagang sendiri, sehingga tidak mengherankan bahwa penandaan ini terlihat sangat tidak teratur.

Perilaku teritorialitas berdasarkan dominasi. Kepemilikan atau hak dalam teritorialitas tergantung kepada persepsi yang bersangkutan (Fisher, 1984 dalam Laurens, 2004). Persepsi tersebut terlepas dari pengaruh legal atau tidak. Kepemilikan ini meliputi segala sesuatu termasuk ruang. Penggunaan ruang secara berlebihan akan menimbulkan perilaku yang dinamakan dominasi. Pada Pasar Inpres Kota Lhokseumawe, perilaku dominasi terlihat pada penggunaan badan jalan sebagai area parkir dan berjualan (Gambar 13). Area parkir ini memiliki peran yang besar dalam mengambil kegunaan badan jalan. Pada area penelitian sendiri, tidak ada peraturan yang khusus mengenai penggunaan dan perluasan area berjualan. Hal ini menimbulkan spekulasi pedagang untuk meluaskan dagangannya sesuai keinginannya. 32 persen diantara pedagang meluaskan dagangannya dengan alasan agar dagangan bisa dilihat (14\%), dagangan terlalu banyak (22\%) dan lahan jualan terlalu sempit (29\%). Selain itu, 68 persen pedagang tidak meluaskan area jualannya dengan alasan menghargai area jualan orang lain (20\%) dan barang dagangan hanya sedikit $(60 \%)$.

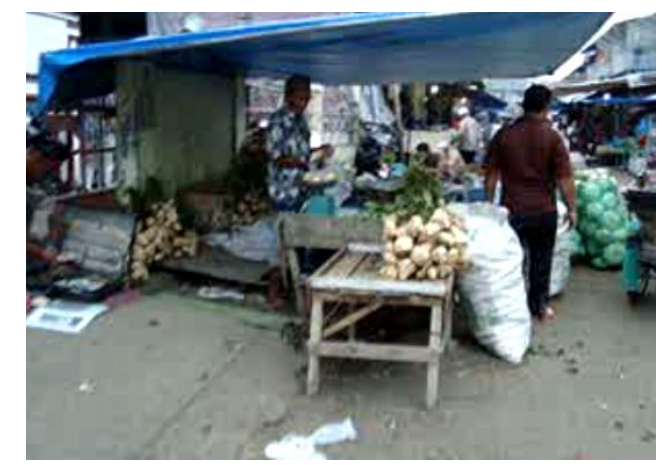

Gambar 13. Penggunaan Badan Jalan sebagai Tempat Parkir dan Berjualan

Dari hasil penelitian, perilaku dominasi terbesar terjadi pada pukul 08.00-10.00 WIB Dominasi ini terdiri dari rentang dominasi untuk parkir dan berjualan yang sangat bervariasi. Untuk parkir dimulai dari $108 \mathrm{~cm}, 163 \mathrm{~cm}, 167$ $\mathrm{cm}, 192 \mathrm{~cm}, 222 \mathrm{~cm}, 267 \mathrm{~cm}$ dan $332 \mathrm{~cm}$. Sedangkan untuk area berjualan dimulai dari 29 $\mathrm{cm}, 46 \mathrm{~cm}, 59 \mathrm{~cm}, 70 \mathrm{~cm}, 80 \mathrm{~cm}, 94 \mathrm{~cm}, 95 \mathrm{~cm}$, $104 \mathrm{~cm}$ dan $213 \mathrm{~cm}$. Berdasarkan potongan dan gambar peta dominasi yang ada, disimpulkan bahwa perilaku dominasi pada area penelitian mengarah pada penggunaan badan jalan sebagai area parkir.

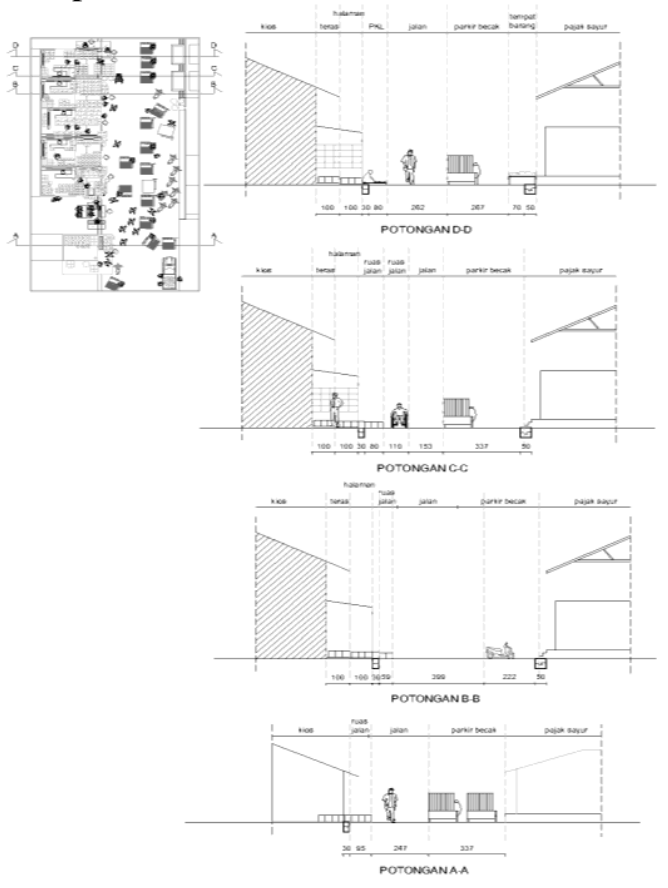

Gambar 13. Rentang Dominasi 
Perilaku teritorialitas berdasarkan control. Kontrol menurut Altman (1975) dalam Burhanuddin (2010) diartikan sebagai mekanisme mengatur batas antara orang yang satu dengan orang yang lainnya dengan menggunakan tanda-tanda yang menyatakan bahwa tempat tersebut ada yang memiliki. Perilaku teritorialitas berdasarkan kontrol terlihat pada perilaku membatasi antara teritori satu dan teritori lainnya. Pada koridor ini, batasan tersebut dilakukan dengan bahan fisik, yaitu elemen masif (dinding, lantai, langitlangit) tenda, tiang dan beton, papan, penataan perabot.

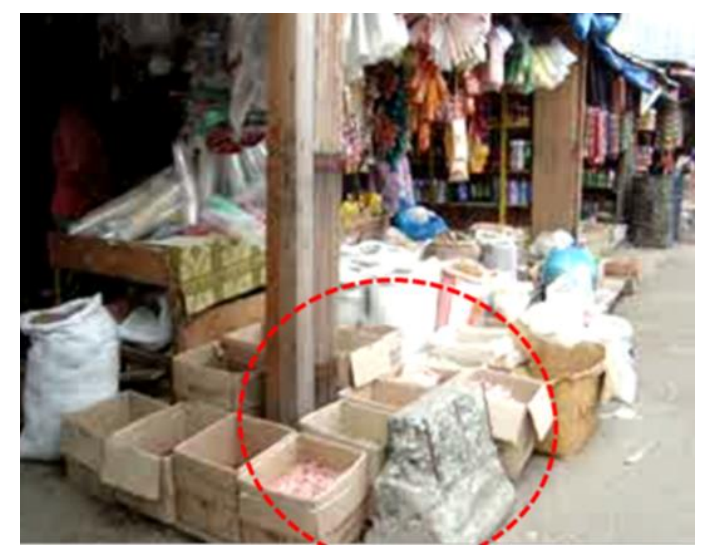

Gambar 14. Pengontrolan Menggunakan Batu dan Tiang

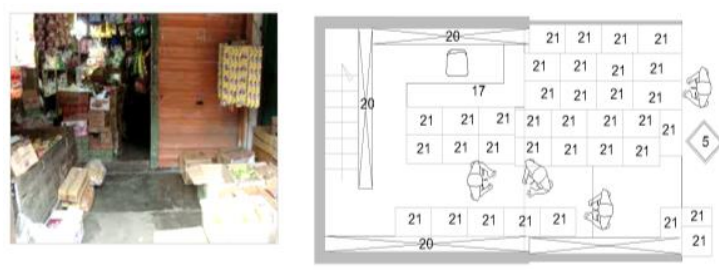

Gambar 15. Pengontrolan Menggunakan Elemen Masif
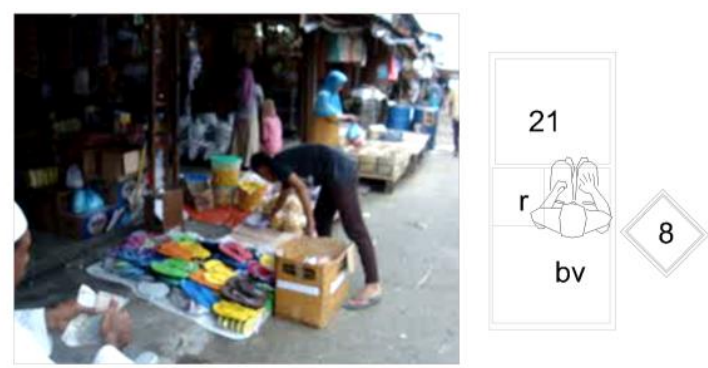

Gambar 15. Pengontrolan Menggunakan Tenda

Pada area penelitian, 66 persen pedagang hanya berjualan sendiri. Mereka lebih memilih dibantu oleh saudara/kerabatnya $(60 \%)$ untuk mengontrol dagangan. Disusul dengan suami/istri sebesar 27 persen dan oleh teman sebesar 13 persen.

Permasalahan yang sering terjadi pada pasar adalah batas teritori. Pada area penelitian, seringkali antara barang yang satu dan lainnya tertukar. Berdasarkan hasil kuisioner, mereka melakukan beberapa tindakan, yaitu membuat batas sebesar 73 persen, membuat jarak antara barang pedagang satu dan pedagang lainnya sebesar 13 persen dan melakukan keduanya (membuat batas dan jarak sebesar 14 persen). Bentuk pengontrolan lainnya adalah menjaga area teritori ketika sedang pergi. Mereka lebih menempatkan saudara/kerabat untuk menjaga teritorinya. Namun, 43 persen pedagang mempercayai tetangga sebelah untuk mengontrol dengan alasan sudah lama berteman (37\%) dan terpercaya (16\%). Walaupun cara ini tidak semua pedagang melakukan, namun dianggap cukup efisien. Berdasarkan konsekuensinya terhadap ruang, perilaku pengontrolan yang tidak teratur menghasilkan visualisasi yang tidak bagus.

\section{KESIMPULAN}

Berdasarkan hasil penelitian mengenai perilaku teritorialitas pada Pasar Inpres Kota Lhokseumawe, ada 4 hal yang diangkat dalam perilaku penggunaan ruang pada pasar ini, yaitu personalisasi, penandaan, dominasi dan kontrol. Pertama, Hasil pengamatan menunjukkan bahwa pengguna (dalam penelitian ini adalah pedagang) Pasar Inpres melakukan personalisasi berupa peneguran, obrolan, berkumpul, perilaku membatasi dagngan serta meluangkan waktu untuk berkumpul untuk menciptakan rasa kekerabatan, aman dan nyaman ketika berada dalam ruang aktivitasnya. namun perilaku ini menandakan bahwa hubungan antara pembeli dan pedagang sangatlah erat. Berdasarkan kaitannya terhadap ruang, personalisasi menciptakan ruang bersama yang terdiri dari dua orang, tiga orang dan seterusnya, berada pada waktu-waktu tertentu dan pada tempattempat tertentu. Kedua, perilaku penandaan dari pengguna pasar sebagai respon untuk mempertahankan dan memperjelas batas area kekuasaannya dari intervensi pihak lain. Perilaku ini diwujudkan dengan menggunakan batas-batas fisik yang terbagi menjadi tiga, yaitu elemen bentuk tetap (lantai, dinding dan langitlangit) yang sifatnya masif, elemen bentuk semi

Edisi cetak 
tetap (tenda, papan, kendaraan, dan perabot) yang dapat berpindah kapan saja, serta elemen bentuk tidak tetap (postur tubuh, gerakan tangan dan lengan serta posisi tubuh). Berbicara tentang pengaruh penandaan terhadap ruang, maka dapat diuraikan berdasarkan ketiga elemen di atas. Pertama, elemen bentuk tetap, menciptakan ruang yang sudah pasti dan sukar dirubah. Waktu tidak berpengaruh terhadp elemen ini.

Kedua, elemen bentuk semi tetap, menghasilkan ruang yang dapat dipindah kapan saja dan di mana saja. Elemen ini paling banyak terdapat pada pukul 06.30-07.00 WIB. Ketiga, elemen bentuk tidak tetap, menghasilkan ruang yang tidak terbatas yang mengitari teritorinya. Elemen ini paling banyak menempati ruang pada pukul 06.30-07.00 WIB. Berdasarkan waktu, ada beberapa waktu yang membuat pasar ini lebih ramai, yaitu pada idul fitri dan idul adha. Sedangkan pada akhir pekan, pasar ini keadaannya sama dengan hari-hari kerja lainnya. Perlu diketahui bahwa, pemerintah hanya menyediakan wadah berjualan. Sedangkan yang mengatur peletakan lapak/los/kios adalah pedagang sendiri, sehingga tidak mengherankan bahwa penandaan ini terlihat sangat tidak teratur.

Ketiga, adanya perilaku dominasi pada teritori publik karena penggunaan ruang untuk parkir dan berjualan. Hal ini menyebabkan kemacetan dan kesesakan pada ruang-ruang dengan intensitas aktivitas yang lebih tinggi daripada yang lain (dalam hal ini aktivitas pada pukul 08.00-10.00 wib). Tidak ada upaya apapun untuk mengatasi perilaku ini, mereka hanya menyesuaikan diri dengan keadaan yang ada dengan memanfaatkan ruang yang tersisa sebagai sirkulasi. Keempat, pengguna melakukan tindakan pengontrolan demi melindungi teritorinya yang tergolong teritori primer, untuk mencegah segala ketidaknyamanan yang akan muncul. Pengguna cenderung menggunakan benda fisik sebagai alat kontrol, yaitu dinding, lantai, langit-langit, papan, tenda serta perabot. Selain itu, pengontrolan teritori terlihat pada perilaku pemiliknya. Dalam keadaan sendiri, mayoritas mereka lebih mempercayai saudaranya untuk menjaga area teritorinya dibandingkan dengan tetangga sebelahnya. Berdasarkan konsekuensinya terhadap ruang, perilaku pengontrolan yang tidak teratur menghasilkan visualisasi yang tidak bagus.

\section{Daftar Pustaka}

Agustin, Alin Pradita; Gagoek Hardiman \& R. Siti Rukayah, 2014. Teritori Pedagang Informal, Jurnal Arsitektur NALARs, 13 (1), 1-10.

Angkouw, Rieka \& Herry Kapugu, (2012) Ruang Dalam Arsitektur Berwawasan Perilaku, Jurnal Media Matrasain, 9 (1), 58-74.

Burhanuddin, (2010) Karakteristik Teritorialitas Ruang Pada Permukiman Padat di Perkotaan, Jurnal Ruang, 2 (1), 39-46.

Cassiophea, Lola, (2012) Pasar Mingguan di Lingkungan Permukiman Jalan Putri Junjung Buih Kota Palangka Raya, Jurnal Perspektif Arsitektur, 7 (1), 25-28.

Creswell, John W, (2012) Research Design Pendekatan Kualitatif, Kuantitatif dan Mixed. Yogyakarta: Pustaka Pelajar.

Dinas Pekerjaan Umum Kota Lhokseumawe.

Egam, Pingkan Peggy, (2009) Intervensi Perilaku Lokal Terhadap Pemanfaatan Ruang Publik, Jurnal EKOTON, 9 (2), 57-63.

Fatimah, Dina, (2010) Gender Dalam Teritori, Jurnal Waca Cipta Ruang, II (II), 1-8.

Hadinugroho, Dwi Lindarto, (2002) Ruang Dan Perilaku Suatu Kajian Arsitektural, USU digital library, 1-16.

Halim, Deddy, (2005) Psikologi Arsitektur, Jakarta: Grasindo.

Haryadi, B. Setiawan, (2010) Arsitektur Lingkungan dan Perilaku, Yogyakarta: Gadjah Mada University Press.

Hidjaz, Taufan, (2007) Desain Interior Dan Perilaku Pengunjung Di Ruang Publik, Dimensi Interior, 5 (2), 61-70.

Hidjaz, Taufan, (2014) Interaksi Perilaku Dalam Suasana Ruang Terbatas Studi Kasus Hotel Kapsul The Pod Singapura, Jurnal Itenas Rekarupa, 2 (2), 74-86. 
Kumoro W, Agung, (2007) Karakter Dan Atribut Ruang Publik Pasar Tradisional Kasus Pasar Legi Surakarta, Jurnal Gema Teknik, 1, 102-106.

Kurniadi, Fery; Diananta Pramitasari dan Djoko Wijono, (2012) Konsep Perilaku Teritorialitas di Kawasan Pasar Sudirman Pontianak, Jurnal Vokasi, 8 (3), 197-208.

Laurens, Joyce Marcella, (2004) Arsitekttur dan Perilaku Manusia. Jakarta: Grasindo.

Putri, Rr; Pangarsa, Galih Widjil dan Ernawati, Jenny, (2012) Pendekatan Teritori Pada Fleksibilitas Ruang Dalam Tradisi Sinoman Dan Bidaya Di Dusun Karang Ampel Malang, Dimensi, 39 (2), 65-76.

Ricardo, David, (2010) Pemanfaatan Marka Jalan Sebagai Batas Teritorial Perilaku Pada Sunday Morning Universitas Gadjah Mada Yogyakarta Kasus Jalan Olahraga Universitas Gadjah Mada Yogyakarta, Jurnal Komposisi, 10 (6), 375-382).

Soukotta, Dwars; Judy O Waani dan Octavianus H.A Rogi, (2014) Klasifikasi Ruang Teritori Publik Pada Rumah-Rumah Di Kampung Jawa Tondano Studi Kasus Di Lingkungan III. Media Matrasain, 11 (2), 61-67.

Tandal, Antonius. N dan I Pingkan P. Egam, (2011) Arsitektur Berwawasan Perilaku (Behaviorisme), Jurnal Matrasain, 8 (1), 53-67.

Waani, Judy O, (2012) Teori makna lingkungan dan arsitektur, Jurnal Media Matrasain, 9 (1), 36-47.

Peta Pajak Inpres Kota Lhokseumawe, http://www.wikimapia.org, diakses 27 Maret 2016. 